\title{
Toward a Cultural Topography of Cave Use in East Timor: A Preliminary Study
}

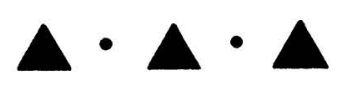

SANDRA PANNELL AND SUE O'CONNOR

A REVIEW OF THE ARCHAEOLOGICAL LITERATURE indicates that most researchers believe that caves and rock shelters are unrepresentative of the range of past habitation activities: while they are "convenient cavities on the landscape for a multitude of human uses ... on an opportunistic basis for a wide variety of purposes ... they represent only a relatively small fraction (albeit situationally variable) of the 'places' so used," constituting "a disproportionately large part of the surviving archaeological record for many prehistoric periods" (Straus 1997:1). Despite this, and owing largely to the paucity or absence of open sites for many periods and in many parts of the globe, archaeologists continue to base their prehistory on the archaeological record derived from cave sequences.

Ian Glover was faced with precisely this dilemma when he carried out his pioneering research in East Timor in the 1960s, as he failed to locate any archaeological open village sites (Glover 1986). He noted that there was little archaeological evidence for change in the nature of cave use as a focus for settlement, despite the transition from hunting and gathering to agriculture ca. 4000 years ago. Aside from the appearance of pottery and the introduction of domestic species, there appeared to be remarkable continuity in the use of caves: the stone artifact assemblages continued essentially unchanged, as did other subsistence-related activities and site features. Ethnographic evidence also indicated the casual nature of cave use by both hunter-gatherers and horticulturalists. Hence he concluded that caves will not be sensitive indicators of cultural or economic change: their occupancy should reflect only a small part of the hunting and collecting aspects of life, with only "simple" artifacts for food preparation or the maintenance of hunting tools likely to be discarded there, artifacts (except pottery) unlikely to alter much from horticultural to hunter-gatherer lifestyles (Glover 1986:206-207).

In this paper we revisit the issue of contemporary cave use in East Timor, with the purpose of providing a more detailed ethnographic discussion of the various uses and meanings of caves. Our study focuses specifically on caves and rock shelters in the regions of Baucau, Com, and Méhara (Fig. 1). Our intention is to go

Sandra Pannell, Rainforest Cooperative Research Centre, James Cook University; Sue O'Connor, Department of Archaeology and Natural History, Research School of Pacific and Asian Studies, Australian National University. 


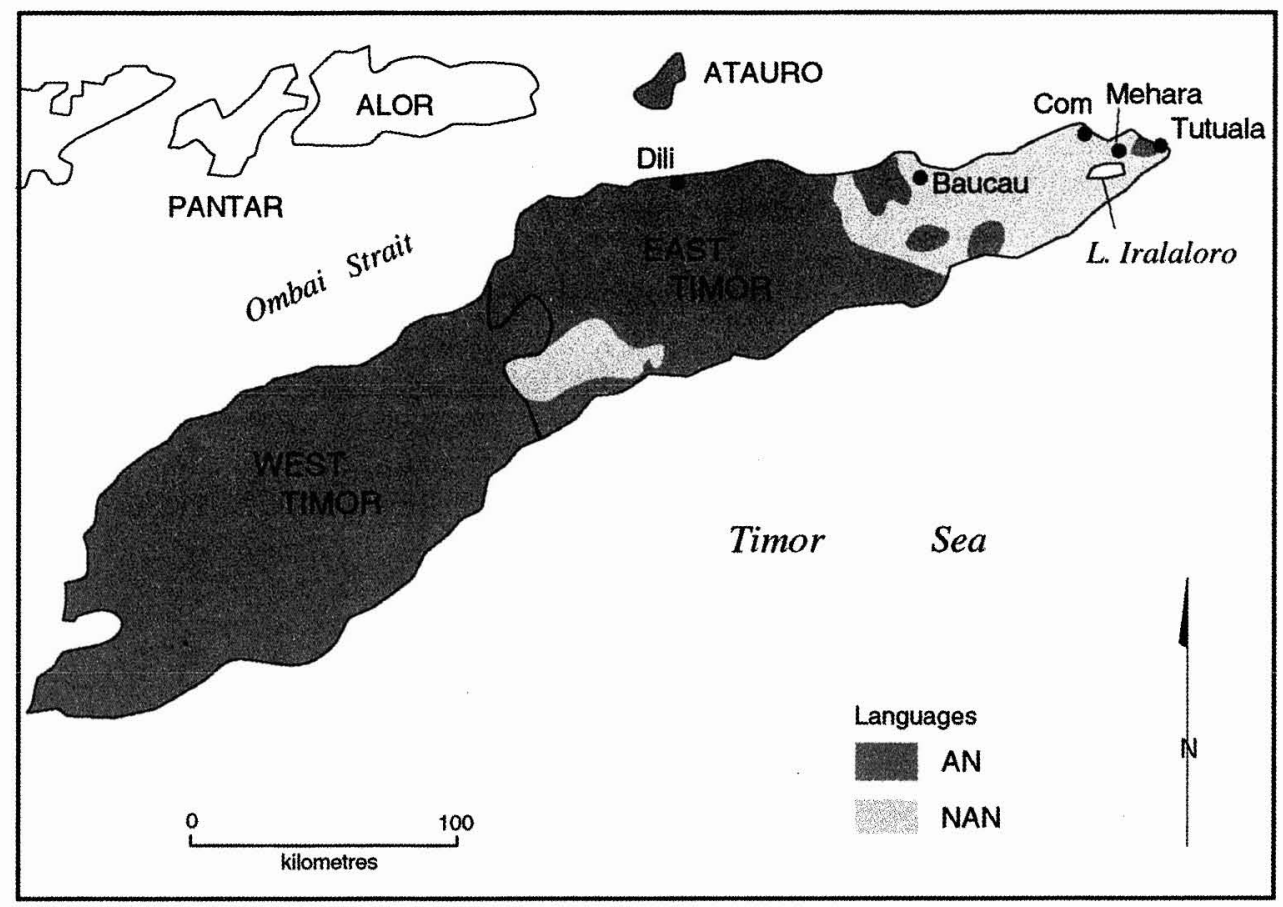

Fig. 1. East Timor, showing locations of main regions discussed in the text and language boundaries (AN: Austronesian; NAN: non-Austronesian).

beyond Glover's view of recent cave occupation as an unrepresentative example of Timorese life, centered upon marginal and seasonal economic activities. We argue that many of the concepts prevalent in interpretation of data derived from archaeological cave and shelter sites assume a degree of fixedness in social use of landscape and consumption and discard of material culture items that find few contemporary parallels. The sparse literature from tropical and semi-arid regions suggests that the notions of "base camps" and "stable village settlements" are probably not very meaningful, either in horticultural or hunter-gatherer contexts. Caves in East Timor occupy a central place in indigenous systems of belief and in the way that recent historical events are remembered. In these particular landscape traditions, caves are communally acknowledged as enduring loci for the convergence of memory and meaning about recent East Timorese resistance and liberation.

\section{CONTEMPORARY CAVE USE IN TROPICAL SEMI-ARID REGIONS}

There have been few anthropological or ethnoarchaeological studies undertaken on contemporary cave use, and even fewer focusing on tropical regions (see Galanidou 2000). Among the Mlabrai forest hunters of northern Thailand, Pookajorn (1985:219) observed that "caves are used only in periods of very heavy rain and wind storms." His data throw doubt on the applicability of the concept of home 
bases, open or otherwise, to the settlement/subsistence pattern of these nomadic tropical-forest dwellers. The trips made by the Mlabrai to reach a temporary camp near a particular resource can last up to ten days, and, once reached, the camps are sometimes occupied for "less time than it took to reach them" (Gorecki 1991:256). In Papua New Guinea, caves today are used as overnight bivouacs for hunting parties, as temporary occupation sites for the processing of sago, for maintenance activities on artifacts, as episodic cooking sites, and, in one case, as a burial niche (Gorecki 1991). On this basis Gorecki questions the characterization of rock shelters by archaeologists as base camps: many caves and open sites function as "field stations" visited and revisited during foraging expeditions from what Gorecki regards as "true residential base camps," that is, sites comprising "proper houses and built structures" spaced within village clusters (Gorecki 1991:256).

In Australia, Nicholson and Cane $(1991: 273)$ report that contemporary Aboriginal people from the eastern semi-arid margins of the Great Sandy Desert limit their occupation of rock shelters "to times of heavy rains," but they note that more than half of the 10 rock shelters they discuss are in fact used for ceremonial purposes - though none of the sites was accorded this status by their Aboriginal informants. The archaeological evidence for the "sacred" nature of these rock shelters is present in the ephemeral form of paintings, engravings, and a single sacred board, and nondescript "sacred stones" derived from roof falls that are of "great significance to Aborigines" but "archaeologically invisible" (Nicholson and Cane 1991:305). Their work also draws out the gender focus in cave use in this arid region.

The view that Australian Aborigines rarely used caves and shelters as residential camps except in very heavy rain is largely derived from studies of occupation in arid regions and understates the importance of such sites as living spaces in subtropical and tropical parts of the continent. In the tropical north of Australia cave and shelter sites functioned as residential camps mainly during tropical monsoonal downpours but were also used to provide shade from the fierce summer sun (Flood 1997:194). In the Kimberley region of Western Australia, sheets of paper bark were hung from the external roofs of the rock shelters and secured at ground level inside the dripline to create a wind- and waterproof living space, which, depending on the size of the shelter, might be occupied by several family groups. These rock shelters saw more continuous and sustained use during the wet season than any other site type and thus deserve the status of main residence or home base for this period (O'Connor 1999:12). Kimberley rock shelters were also used as the final repositories for the dead (secondary bundle burials) and as art and ritual sites when rock art panels of wandjina figures were retouched with pigment at the end of the dry season in order to ensure the arrival of the monsoon and with the rains the renewal and increase of all life (Utemara and Vinnicombe 1992).

To assess cave and rock shelters merely in terms of the number of hours per person per day they were in use, the number of calories consumed by people camping in them, and so on diminishes these sites in terms of the significance they hold within the landscape and the ideological system in which they operate. In the case of the Kimberley shelters, for example, the act of repainting the wandjina was regarded as essential, as it reified and united all aspects of the physical and cultural landscape (Mowaljarlai et al. 1988:691). 
The ethnographic settings for this paper are the suco or village cluster of Tirilolo on the Baucau Plateau and the village clusters of Com and Méhara (Fig. 1), which share a boundary and common language, at the east end of the island. Tirilolo comprises four villages (povoaçoes), each with a population of no more than 100 people: Wai Sa, Parlamentu, Cai Sido, and Lia Lai Lessu (also known as Lessi). Com is close to the deep port of the same name. Méhara is inland on the main east-west road midway between Los Palos and Tutuala and close to the largest freshwater lake in Timor, Iralaloro. The locations of all three suco are recentcompulsory relocation of settlements to the road and coast was a deliberate outcome of first Portuguese, and then Indonesian, occupation. (All old villages identified to us are in elevated naturally fortified locations deep in the forest, away from the current road and coastline.) The residents of the Tirilolo and Com/ Méhara districts speak two very different languages, Waima'a (also known in the literature as Waimoa: Wurm and Hattori 1981:40; and Uai Ma'a: Hicks 1976:6) and Fataluku. Waima'a, spoken by ca. 3000 people on the Baucau Plateau immediately west of the town of Baucau, is identified as an endangered Austronesian (or AN) language of the Central Malayo-Polynesian language group (Blust 1993). Fataluku is a Papuan (non-Austronesian or NAN) language belonging to the Trans New Guinea phylum, with an estimated 25,000 speakers residing in the area from Tutuala, at the eastern tip of the island, west to the area of Lautem (Wurm and Hattori 1981:40).

The Baucau Plateau is a sparsely vegetated region with poor soils, further degraded by land clearing and goat-herding activities. Corn, the food staple, is grown in small, rubble-walled enclosures in the wet season (January to March), and around four permanent springs. Mango, papaya, and breadfruit trees and other crops such as beans, tomatoes, and tobacco are also grown at these springs, while tamarind trees can be found growing wild on the limestone terraces. Tobacco, peanuts, goats, and lontar palm juice and spirit are sold in the local market of Baucau and provide an important source of monetary income in what appears to be a limited cash economy. Although some of the villages are in close proximity to the sea, fishing and other marine-based subsistence activities do not appear to be an important feature in the local economy.

The people of the Com district, by contrast, regularly carry out limited inshore reef fishing and foraging, with small fish, octopus, and clam supplementing the staples of corn, cassava, various kinds of yams, and beans. Similarly in the Méhara district, the catfish and bream of Lake Iralaloro supplement the vegetable staples and sawah (wet rice) of the villages on its northern shore. The large herds of water buffaloes and horses grazed on the grassy floodplains by the lake are an important form of currency in the local ritual economy, involving mortuary and marriage prestations. Tobacco is also grown in these districts, as on the Baucau Plateau, as a cash-producing crop. There appears to be little reliance on marine resources, although villagers will exploit these resources when their hunting activities take them within close proximity of the sea. (Accessing the coast in this area involves a good $10 \mathrm{~km}$ walk through the forest and a steep $400 \mathrm{~m}$ descent from the top of the limestone terraces.) The large expanses of primary- and secondary-growth 
rainforest in the fertile and well-watered Méhara district are also a source of economically important stands of bamboo and sugar palm and home to various species of game birds, together with deer, wild pigs, monkeys, civet cat, and cuscus, which are regularly hunted by local people.

While "li'e" and "veraka" are the generic terms in Waima'a and Fataluku for a range of "cave" formations, not all so-called "caves" are known by these terms. In both regions, caves are given specific names that may refer to mythological events, ancestral figures, the physical features of the formation, or its particular ritual status. In the Com district, for example, Poinorili Maunorili is the name given to a 30-m-high cliff face with a very narrow overhang. According to local accounts, a large flood caused by incessant rainfall and rising sea levels killed everyone except for a Fataluku woman (poi) and man (mau) left on top of the limestone terraces at Poinorili. The woman lived high up on the cliff face, while the man resided at the base. In order to have sex, the woman lowered a rope down from her cliff-top residence and the man climbed up, leaving his seven hunting dogs at the bottom. In due course, the man and the woman had seven daughters and seven sons. The residents of this region state that the entire population of East Timor originated from the (incestuous) unions of these ancestral offspring. Not far from this cave is a series of caves called Kakira Vér, one of which in 1997 was transformed into a religious grotto containing a statue of the Virgin Mary. A Catholic sister from the congregation of Manatuto had a dream in which she was instructed by a divine personage to place the statue in this particular cave. Prior to becoming a shrine of the Virgin Mary, the cave was occupied on a permanent basis by the now deceased landowner.

While caves are identified as places to hunt wild animals such as cuscus and bats and to collect honey and bird nests, they are also regularly used to corral domestic animals such as goats and water buffaloes (Glover 1986:90; Fig. 2). The dung produced by the penned animals provides invaluable fertilizer for adjacent corn and tobacco gardens.

On the Baucau Plateau, several shallow overhangs located near the sea are named Lié Kéré or "cave with markings or lines." These "caves" or sea cliff rock faces are art sites displaying a range of anthropomorphic and other kinds of motifs, among which boats figure prominently (Glover 1972, 1986; O'Connor 2003). As Glover noted, many of these boats are reminiscent of the "ships of the dead" found throughout Island Southeast Asia and also the stylized high-prowed boats on the shoulders of Dongson drums. Elsewhere in Island Southeast Asia, boat burials are often placed in caves in association with these motifs, and Glover (1972:42) records that at the time of his visit in this part of Timor coffins were "regularly made in the form of a boat for the journey of the spirit to its ancestors over the sea." The motifs in the caves therefore link the sea with the land and the living with the dead. Most of the people we interviewed on the Baucau Plateau and in Méhara regarded the rock art as produced by the actions of natural, rather than cultural, agents, either as self-generating or as simply being "from the time of the ancestors." In the Tutuala region the art was said to appear and disappear at different phases of the moon. Deliberate defacement of some panels was noted during recording of the art sites, ranging from scratching of individual motifs to reveal fresh limestone to extensive shell damage that had removed large areas of 


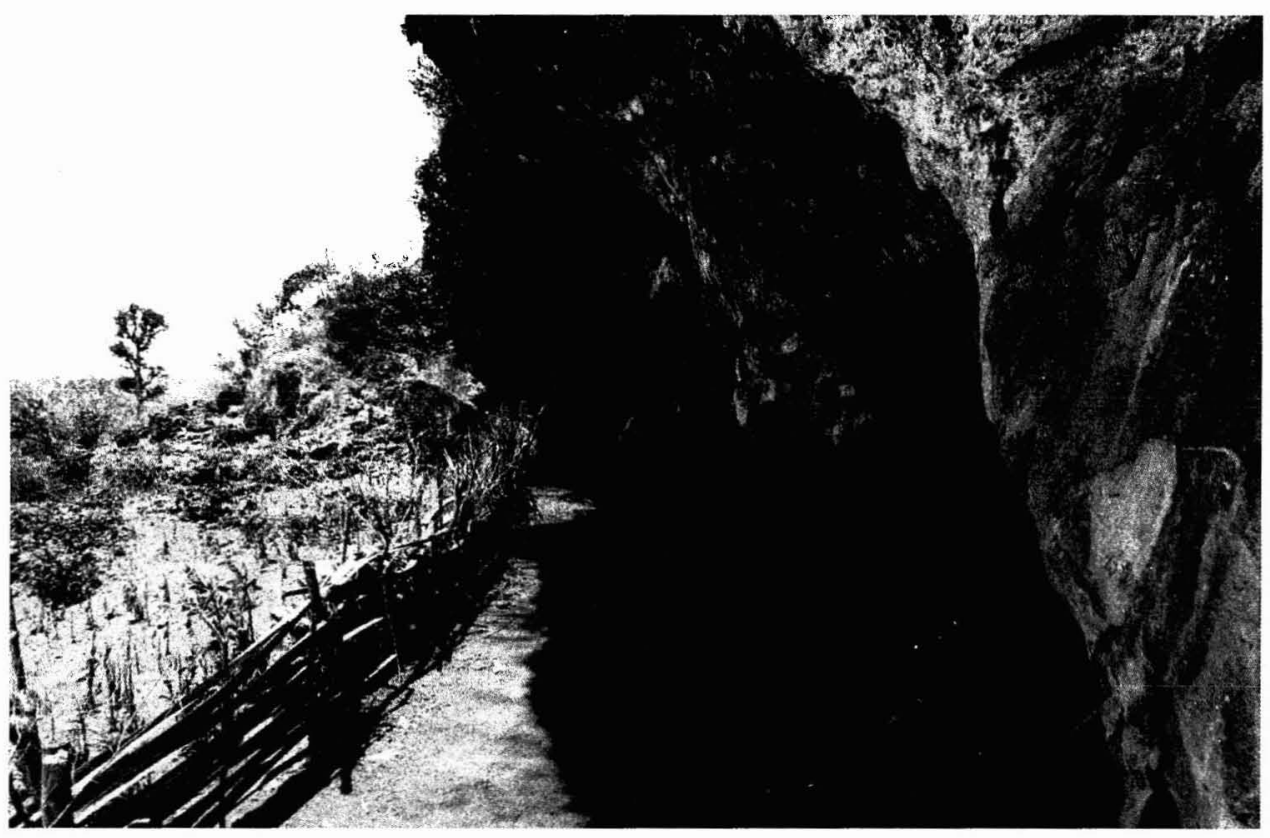

Fig. 2. Large fenced shelter on the Baucau Plateau. (Photograph: Sue O'Connor)

panels resulting from mortar fire from the Indonesian navy. We were told that the Indonesian army regularly tried to remove these symbols of East Timorese culture when they came across them in the forest.

Some caves also contain built stone structures, platforms, standing stones, and graves associated with the ancestors (Fig. 3). In some caves these adat platforms and standing stones are in regular use and animals are sacrificed on the platforms and gifts of palm spirit and food are left for the ancestors. Stone adat platforms are also found within the old stone walled fortified village sites (kampung lama) and at various locations within the forest.

In the dry environment of the Baucau Plateau, where the few permanent springs are some distance apart, the seepage in caves is an important and sustaining source of clean water, regularly consumed by people on their way to tending their gardens or by hunters passing through the area (Fig. 4). The name of one cave, Tjuputjupu, literally means "water that falls in drops." Water is collected in large clam shells and bottles, some dating to the Portuguese period. The water thus collected sustains a range of subsistence activities. A cave in the Méhara district is called Léla Méré, "the place of glue"; the name refers to a species of vine found locally that produces a milky fluid that, mixed with soil, is used to seal the pottery containers employed by local people in the production of palm spirit (tua araki), which takes place at this cave site, surrounded as it is by sugar palms (Arenga saccharifera) or tua marau. Palm spirit distilleries were also recorded at Matja Kuru. Several caves in Méhara are used for processing bamboo, which is used in house and furniture construction, for piping in palm spirit distilleries, to carry water, and for storage of locally grown produce such as corn. 


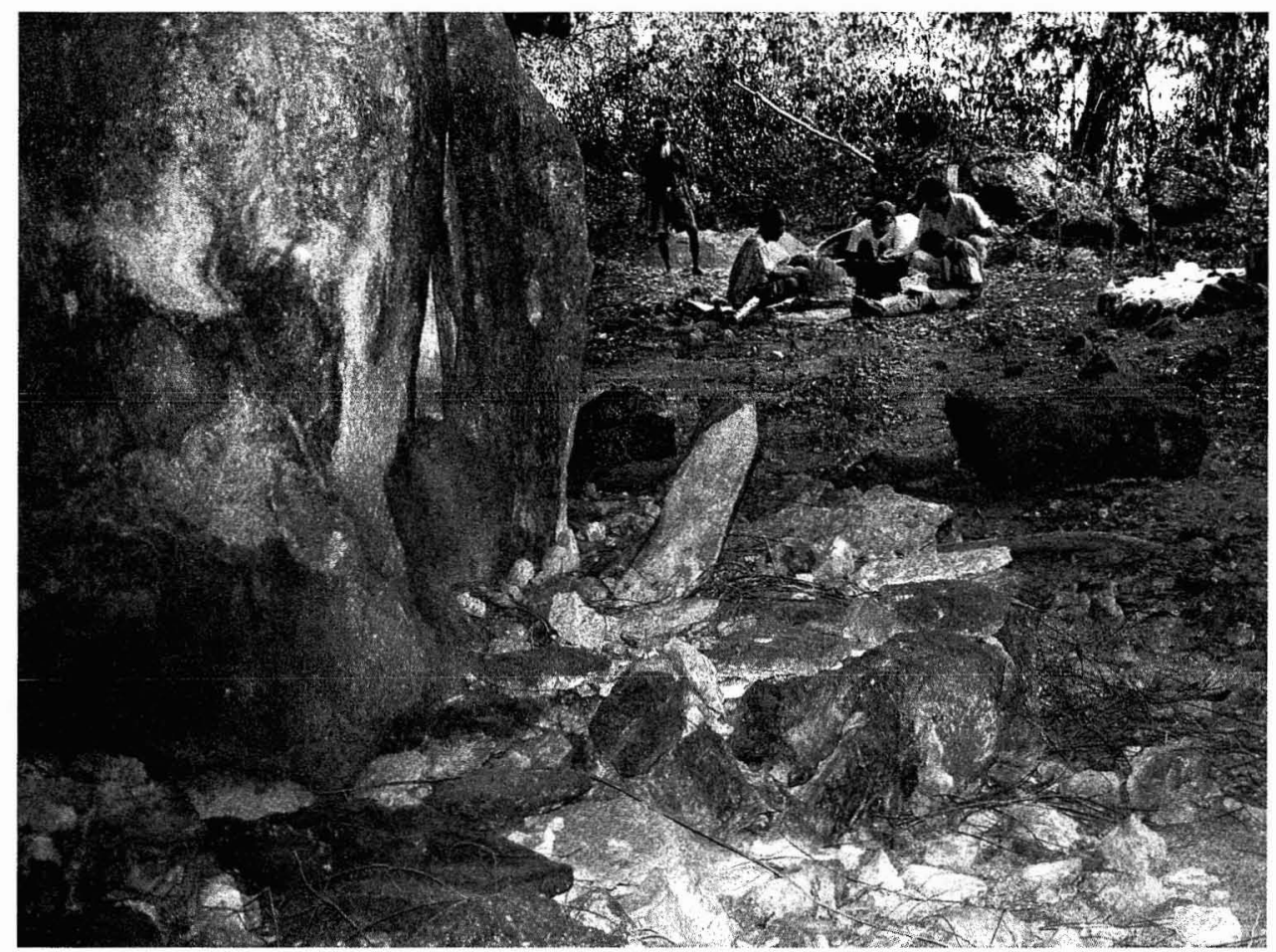

Fig. 3. Adat platform where animals are sacrificed to the ancestors in Lene Hara cave, Tutuala. (Photograph: Sue O'Connor)

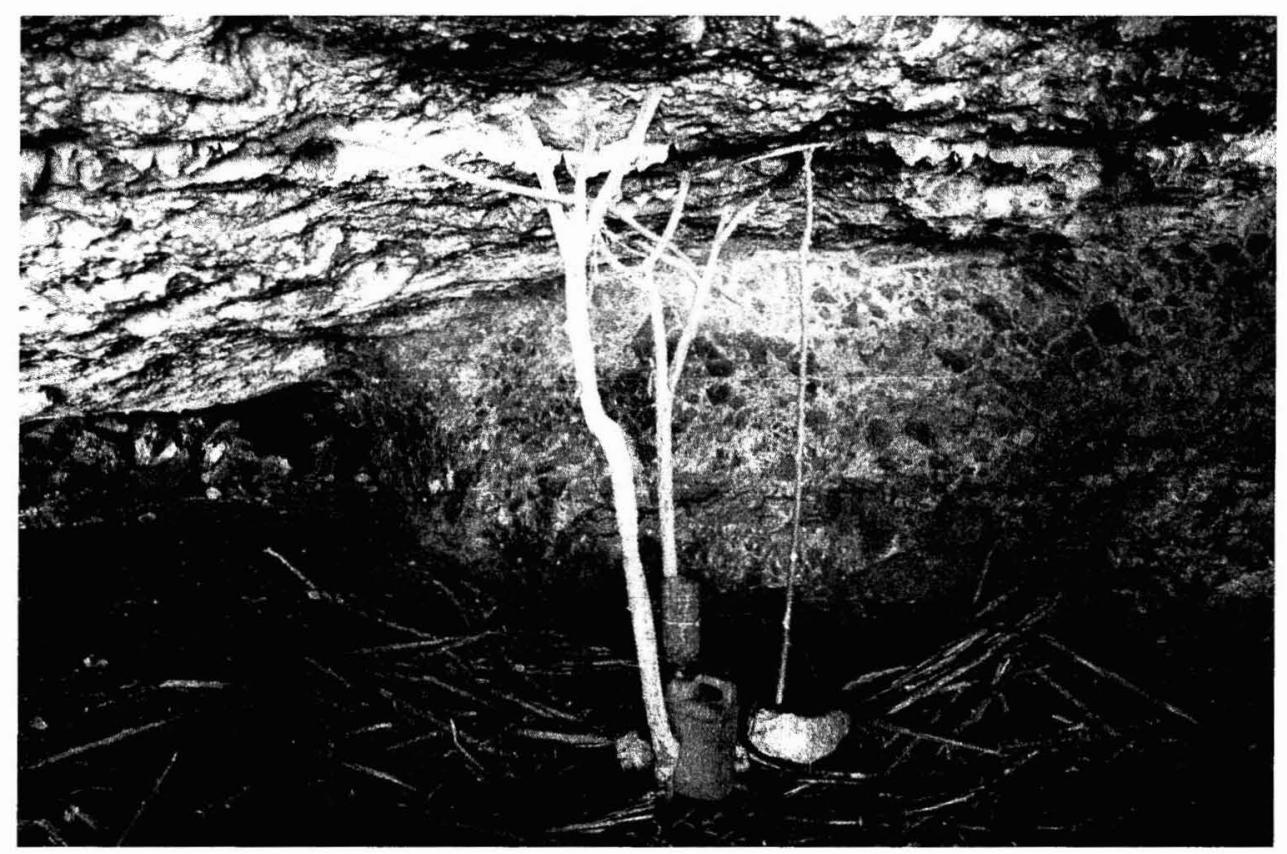

Fig. 4. Elaborate device for collecting drops of water from cave roof. (Photograph: Sue O'Connor) 


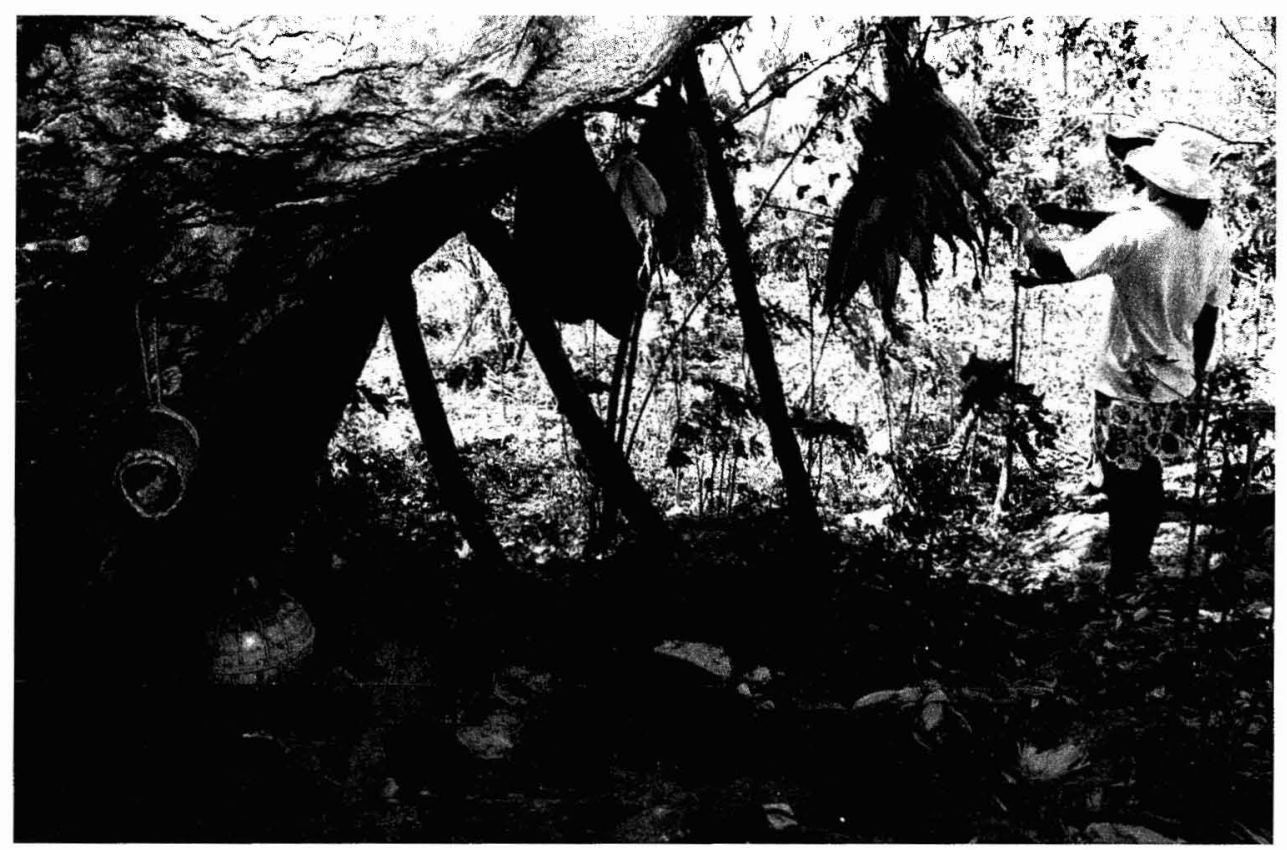

Fig. 5. Small cave on the Baucau Plateau with corn, sleeping mat, and other personal items. (Photograph: Sue O’Connor)

Caves serve as secure, dry storage sites for corn, tobacco, beans, and personal items (Glover 1986:90). Among the other utensils and artifacts regularly used and found in caves are sharpening stones, chert flints, round manuports used in games, and an array of wooden pegs inserted at varying heights in the cave wall. From these pegs hangs a range of domestic items, including containers of salt, betel nut pouches, and cigarettes (Fig. 5). Hanging from the limited wall space of the small rock shelter on the Baucau Plateau known as Watu Boku Waké ("the overhanging round rock") was a monkey's tail, probably a talisman to protect individual property from theft or damage. A number of caves contained bamboo sleeping platforms, often used during the midday rest period by individuals preparing palm spirit or at their gardens. Depending on the distance of the cave from the village, these sleeping platforms may also be used for overnight stays. Depending on the season and the subsistence activity, some cave sites are continually occupied for a number of weeks, if not months.

We recorded one instance of permanent cave occupation at a series of interconnected large galleries known as N'haumo ("the house of the eagle") on the Baucau Plateau (Fig. 6). N'haumo is occupied by a 70 -year-old bachelor, Dégu Kai Wa, whose occupation of this cave site is a picture of near self-sufficiency. During the day Dégu either tends his nearby corn, bean, yam, and tobacco gardens, or uses snares and a blowpipe to hunt monkey, bush fowl, and pigeons within the cave and on the surrounding terraces. A bird-hunting hide was constructed in this cave. On these hunting trips he may also collect tamarind pods (kai malé), wild honey, and the bark of the gomu tree (which he uses to make rope). At times, he makes the steep descent to the sea to go fishing and harvest 


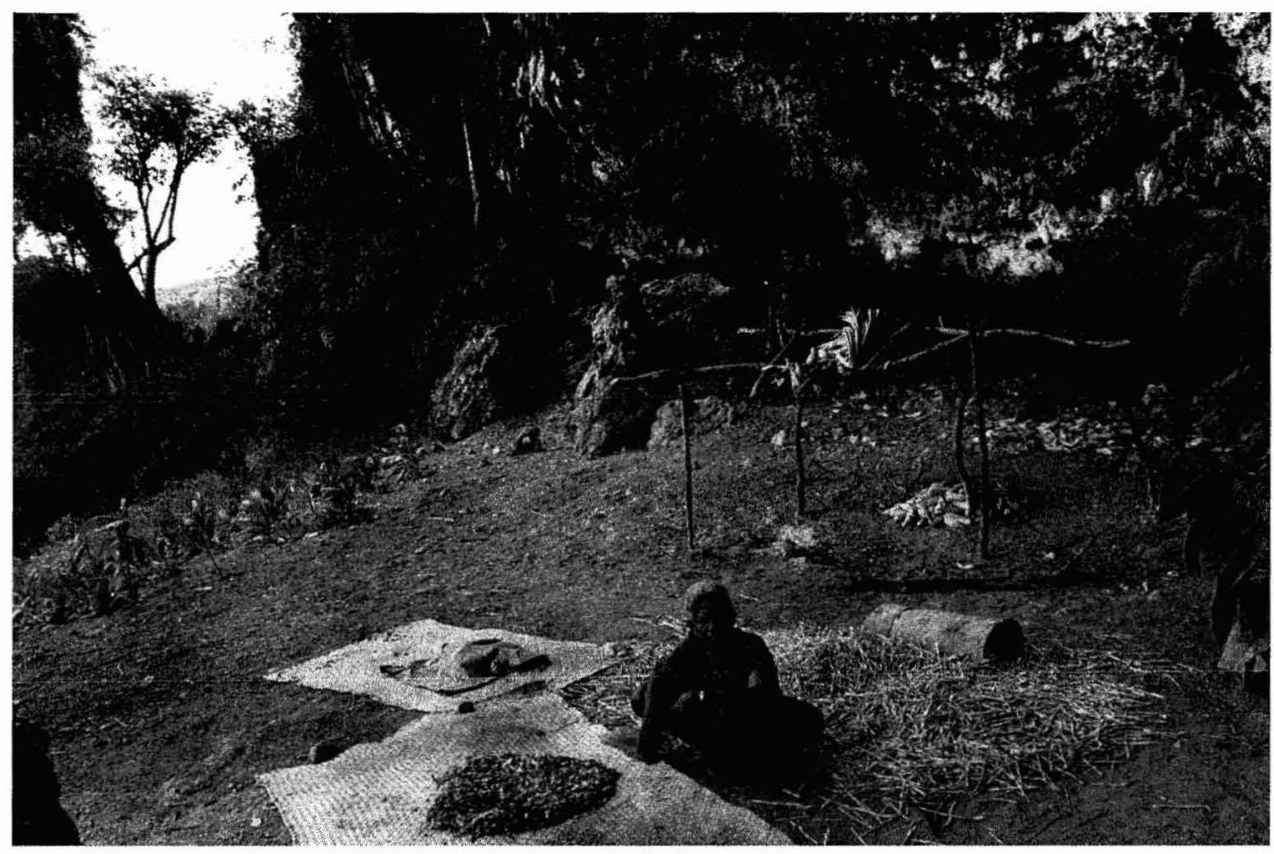

Fig. 6. Dégu Kai Wa, a 70-year-old bachelor, preparing his tobacco crop at his cave home, N'haumo, on the Baucau Plateau. (Photograph: Sue O'Connor)

salt. At night he sleeps on a woven lontar leaf mat at one end of the gallery complex. All of Dégu's drinking water is collected from natural seepage through the roof of the cave and kept in a handmade pottery receptacle. Growing along the dripline of the galleries are papaya, mango, and breadfruit trees planted by Dégu. The immature fruit and the leaves from these trees are fed to a pig coralled in a rubble-wall pen constructed around a small rock overhang. Dégu sharpens his machete on a locally obtained stone (watu wau) and uses a chert flint (watu kilé) obtained from the region of Laga to the east and kapok from a nearby tree to strike up a fire for cooking. Food and other personal possessions are stored in woven lontar-leaf baskets and containers hung from wooden pegs. With the exception of his old aluminum cooking pot, the pottery water jar, and an unused UNTAET-issue blanket, the utensils and artifacts he uses are all made by him from natural resources found locally.

\section{CAVES AS FOCAL POINTS IN LANDSCAPES OF STRUGGLE}

East Timor is also a land of "hidden histories" (Bird Rose 1991), where silence, denial, and complicity have blanketed the often violent experience of enforced occupation: the 450 years of Portuguese colonial rule, the brief but brutal Japanese occupation (1942-1945) during World War II, and, especially, the 25-year invasion by Indonesian security forces (Aditjondro 2000; Human Rights Watch 1994, 1995, 1997, 1999). Caves and former stone-walled village sites (BI kampung lama, Fataluku lata irata) feature as focal points in this "landscape of struggle."

People speak of everyday survival and the years of armed resistance to the Indonesian forces as a constant movement between roadside village sites and the 
nearby forest or the mountains. For people in the Baucau region, "the forest" refers to the sparsely vegetated limestone terraces, while for those in the Méhara and Com district, "the forest" is the densely vegetated area between the present village site and the coast. Although some resettlement was carried out during Portuguese colonial rule, most resettled communities were established by the Indonesian government in the first years of occupation. As Feldman so graphically illustrates in his discussion of political terror and violence in Northern Ireland, the exercise of power is "contingent on the command of space and the command of those entities that move within politically marked space" (Feldman 1991:8). For local people, their traditional sites are located in the forest, where old village sites and caves are spaces inhabited by ancestors and other powerful beings. The ongoing occupation of the forest is mediated by the maintenance of these relationships.

At times during the Indonesian occupation, entire villages fled to the forest or the mountains and took refuge in caves. In the months leading up to the 1999 referendum, when the militia gangs went on a rampage throughout East Timor, the entire population of the village of Cai Sido took refuge in the large but wellconcealed cave known as Lié Mata Rata, just as they had during World War II when fleeing from the Japanese occupying forces (see Glover 1986:127). Most of the population of the Méhara district fled to caves in 1976 and 1977, and again in 1999 at the height of the militia violence. The cave known as Telupunu was permanently occupied by five families (numbering more than 30 people) between 1975 and 1977. This site was excavated in 2002 by Matthew Spriggs as part of the East Timor Archaeological Project (Veth et al. 2005) and the cave, site furniture, domestic items, personal belongings, and surface features were mapped prior to excavation (Fig. 7). Although the extant sleeping platforms in the eastern part of the cave were erected by Falintil fighters when they briefly reoccupied the cave in 1982, other artifacts and spatial arrangements had changed little since the families left in 1977. When we visited Telupunu in 2002 with some of the previous occupants, they were able to describe in detail their living arrangements within the cave and their strategies for subsistence and survival during their two years of hiding in the forest.

Caves were often used as temporary headquarters for Falintil's operations. Xanana Gusmao, president of East Timor and former leader of the Falintil guerilla force, was among the freedom fighters who sought refuge in Méhara caves. The nature of warfare in this part of East Timor required the Falintil to move constantly, and there are few visible traces in these caves of nearly 25 years of occupation. Falintil forces used few nonperishable materials, and while guns and ammunition were used, gunfire was minimized because of the unwanted attention it attracted.

An important element in the development and success of the independence movement was its material and political recolonization of traditional spaces. The command of the forests and mountains by Falintil guerillas signaled a reclamation of local culture, discursively focused as it is upon caves, ancestral villages, and other places within this geography. The emplacement of East Timor's recent history of violence and resistance in the forests and mountains is also an important element in an emerging national identity. In the district of Méhara, people's reoccupation of the forest during the Indonesian period is often invoked to illus- 


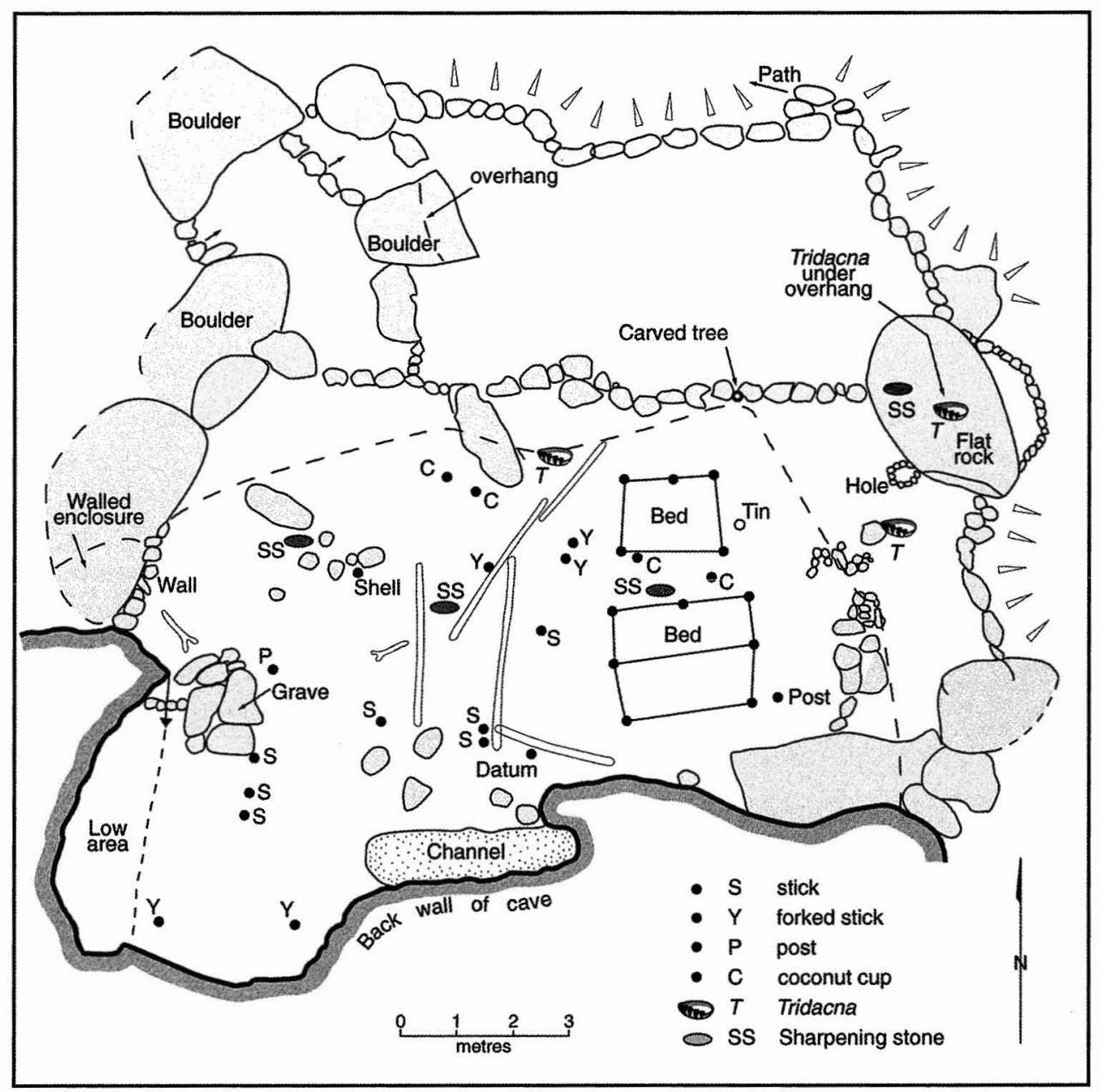

Fig. 7. Plan of Telupunu cave, Com. (Drawn by M. Spriggs, 2002)

trate the new relationship between citizenry and state: local villagers and the national president alike shared the experience of being cave-dwellers.

\section{DISCUSSION AND CONCLUSION}

Glover's view that caves rarely serve as permanent home bases was predicated in part on his contemporary observations and in part on his reconstruction of numbers of pots and stone artifacts in his excavated caves: he estimated maximum discard rates of one pot every 44 years and one retouched stone artifact every four years (Glover 1986:207). He also noted the paucity of items of material culture dating to the colonial period, such as glass, glazed ceramics, cloth, and metal buttons and buckles, that might be expected to survive well in archaeological contexts. Leaving aside the problems inherent in estimating intensity of site use on the basis of artifact discard calibrated against radiocarbon dates, we question Glover's expectations of rates of consumption. Our own experience is that there are 
few value goods in the possession of local East Timorese people and that those few are regarded as too valuable to use. We did on one occasion find entire pieces of blue-and-white Chinese trade ware and Celadon dating to the fifteenth and sixteenth centuries in a cave in the Méhara region, but these were ritual objects that had not been discarded as a result of breakage. Prior to the widespread destruction of traditional adat houses by the Indonesian army, such items were kept as sacre, hidden within the houses or placed within graves - they were rarely placed in domestic circulation. Even today metal buttons and buckles are removed from clothing as it wears out and recycled onto new cloth. Portuguese glass bottles dating to the nineteenth and early twentieth centuries and more recent glass bottles are found in caves and in other dwellings and are still being recycled. Dégu has very few items of material culture; most are made of perishable materials, and the few that are not, such as the stone flint and his single water and cooking pot, have been in use throughout his time of residence.

These caves and shelters in East Timor may contain sparse residues of human occupation not because "caves were at no time, permanent living sites" (Glover $1986: 207)$ but rather because so little was thrown away during the time they were occupied. Similarly the lack of value goods in such sites may simply reflect the lack of value goods within the system, rather than the fact that such goods were discarded elsewhere. Our study also questions the validity of the dichotomies inherent in the use of definitions such as "ephemeral/temporary/specialized camps" = "caves/shelters" versus "base camps/permanent/generalized camps" = "stable village settlements/open sites with built structures." Clearly, the contemporary landscape use of both caves and open sites on East Timor is highly flexible. Finally, this study indicates that caves connect people to the wider physical and ideological landscape. Several of the caves we investigated can be classified as "ideo-technic artifacts" in that they house built structures such as ritual stone platforms and standing stones, and contain paintings that connect them and their users to the ancestors (Dolukhanov 1997:12; Soffer 1985). Caves also feature in the contemporary ideological landscape; as symbols of the 25 years of struggle for independence, they represent monumental landmarks in the nation's history.

\section{ACKNOWLEDGMENTS}

We would particularly like to thank Virgilio Simith, the East Timorese Secretary of State for Education, Culture, Youth, and Sport, for his encouragement and support of our research since 2000. Access to caves in the regions of Com and Méhara was made possible by the Kepala Desa of Com, Edmondo De Crus, and the Kepala Desa of Méhara, Amaduro Sampaiyo, and the help of the communities of both regions. Paolo Da Costa from Tutuala and Tardio Lopes of Poros were also generous with information and access to sites. We would particularly like to thank Edmondo De Crus and his family for their tremendous hospitality during our survey in Com. This project was funded by the Australian Research Council and the Australian National University.

\section{REFERENCES CITED}

Aditjondro, George J.

2000 Menyongsong Matahari Terbit di Puncak Ramelau: Dampak Pendudukan Timor Lorosa'e dan Munculnya Gerakan Pro-Timor Lorosa'e di Indonesia. Jakarta: Yayasan Hak dan Fortilos. 
Bird Rose, Deborah

1991 Hidden Histories: Black Stories from Victoria River Downs, Humbert River and Wave Hill Stations. Canberra: Aboriginal Studies Press.

Blust, Robert A.

1993 Central and Central-Eastern Malayo-Polynesian. Oceanic Linguistics 32:241-293.

Dolukhanov, Pavel $M$.

1997 Cave versus open-air settlement in the European Upper Palaeolithic, in The Human Uses of Caves: 9-13, ed. C. Bonsall and C. Tolan-Smith. British Archaeological Reports International Series 667. Oxford: Archaeopress.

Feldman, Allen

1991 Formations of Violence: The Narrative of the Body and Political Terror in Northern Ireland. Chicago: University of Chicago Press.

FLOOD, JOSEPHINE

1997 Australian Aboriginal use of caves, in The Human Uses of Caves: 193-200, ed. C. Bonsall and C. Tolan-Smith. British Archaeological Reports International Series 667. Oxford: Archaeopress.

Galanidou, Nena

2000 Patterns in caves: Foragers, horticulturalists, and the use of space. Journal of Anthropological Archaeology 19:243-275

Glover, IAN C.

1972 Excavations in Timor. Ph.D. diss. Research School of Pacific Studies, Department of Prehistory, Australian National University, Canberra.

1986 Archaeology in Eastern Timor, 1966-67. Terra Australis 11. Canberra: Australian National University, Research School of Pacific Studies.

Gorecki, PaUl P.

1991 Horticulturalists as hunter-gatherers: Rock shelter usage in Papua New Guinea, in Ethnoarchaeological Approaches to Mobile Campsites: Hunter-Gatherer and Pastoralist Case Studies: 237-262, ed. C. S. Gamble and N. A. Boismier. Ann Arbor, MI: International Monographs in Prehistory.

Hicks, David

1976 Tetum Ghosts and Kin. Prospect Heights, IL: Waveland.

Human Rights Watch

1994 The Limits of Openness: Human Rights in Indonesia and East Timor.

1995 Deteriorating Human Rights in East Timor.

1997 Deteriorating Human Rights in East Timor.

1999 Human Rights Watch World Report: Indonesia and East Timor.

Mowaljarlai, David, Patricia Vinnicombe, Graeme K. Ward, and Christopher Chippendale 1988 Repainting of images on rock in Australia and the maintenance of Aboriginal culture. Antiquity 62:893-895.

Nicholson, Annie, and Scott Cane

1991 Desert camps: Analysis of Australian Aboriginal proto-historic campsites, in Ethnoarchaeological Approaches to Mobile Campsites: Hunter-Gatherer and Pastoralist Case Studies: 263-354, ed. C. S. Gamble and N. A. Boismier. Ann Arbor, MI: International Monographs in Prehistory.

O'CONNOR, SUE

1999 30,000 Years of Aboriginal Occupation: Kimberley, North West Australia. Terra Australis 14. Canberra: Australian National University, Department of Archaeology and Natural History.

2003 Nine new painted rock-art sites from East Timor in the context of the western Pacific region. Asian Perspectives 42(1): 96-128.

Pookajorn, Surin

1985 Ethnoarchaeology with the Phi Tong Luang (Mlabrai): Forest hunters of northern Thailand. World Archaeology 17(2): 206-221.

SOFFer, Olga

1985 The Upper Palaeolithic of the Central Russian Plain. Orlando: Academic Press. 
Straus, Lawrence G.

1997 Convenient cavities: Some human uses of caves and rock shelters, in The Human Uses of Caves: 1-8, ed. C. Bonsall and C. Tolan-Smith. British Archaeological Reports International Series 667. Oxford: Archaeopress.

Utemara, David, and Patricia Vinnicombe

1992 North-western Kimberley belief systems, in Rock Art and Ethnography: 25-26, ed. M. J. Morwood and D. R. Hobbs. Occasional AURA Publication 5. Melbourne: Australian Rock Art Research Association.

Veth, Peter, Matthew Spriggs, and Sue O’Connor

2005 Continuity in tropical cave use: examples from East Timor and the Aru Islands, Maluku. Asian Perspectives 44(1): 180-192.

Wurm, Stephen A., And Shiro Hattori

1981 Language Atlas of the Pacific Area. Canberra: Australian Academy of the Humanities.

\begin{abstract}
In his seminal work on the archaeology of East Timor, Ian Glover (1986) notes that there appeared to be little archaeological evidence for change in the nature of cave use as a focus for settlement, despite the subsistence changes that occurred with the transition from hunting and gathering to agriculture. Looking to the ethnographic record for hunter-gatherer groups, he found little evidence to support the expectation that caves served as "permanent home bases" and commented that "at a time when stable village settlements existed in Timor it is inevitable that the caves provide an even more biased sample of the total Timorese way of life ..." (1986:206). In this paper we revisit the issue of contemporary cave occupation in East Timor with the purpose of providing a more detailed ethnographic discussion of the caves' various uses and meanings. These encompass both the sorts of secular uses described by Glover as well as the social status of caves as sacred or in other ways significant natural formations in the cultural topography of local and national landscapes. The implications some of these observations on contemporary cave use hold for the interpretation of the archaeological record are briefly explored. We also review the sparse literature on contemporary cave use for tropical and tropical semi-arid regions and conclude that the notions of "permanent home cases" and "stable village settlements" are probably not very meaningful, either in contemporary horticultural or past hunter-gatherer contexts. KEYwORDS: contemporary cave use, East Timor, ethnoarchaeology, Island Southeast Asia.
\end{abstract}

